\title{
PREVENTION OF TRAUMATISM AND OTHER RISKS DURING PHYSICAL TRAINING LESSONS
}

\section{Olena Demianchuk, Oksana Modryk}

\author{
Lesya Ukrainka East European National University
}

Demianchuk O., Modryk O., (2014) Prevention of traumatism and other risks during physical training lessons. Health Problems of Civilization 3 (8) p. 20-24.

\begin{abstract}
Summary: Scientific and methodological literature is analyzed in the article, basic regulatory acts governing the issues of preservation of children's health are also considered; opinions are outlined and the reasons which , as the authors of the article believe, stipulate the current situation. Theoretical analysis of the problem of the sanatory program implementation in the modern school education is carried out. The results proving the advisability of usage of the Rufje test for the division of the children into the groups at the physical training lessons are set forth. Correctly developed and implemented technique of physical exercises at the physical training lessons and athletic training will allow overcome negative tendencies, to improve the children's health and to provide differentiated approach to the pupils at the lessons. Health is the state of complete physical, spiritual and social prosperity, but not only the absence of illnesses or physical disabilities. According to the definition of concept of health, by the concept of healthy lifestyle in the widest sense everything in human activities, that favors the preservation and strengthening of health, and everything, that assists a person to perform private and social functions, is being accepted. In specific biological-and-medical sense the healthy lifestyle includes in itself the harmonious way of work and rest combination, optimal nutrition, physical activities, hygiene keeping, the absence of harmful habits, positive attitude towards social surrounding and to life in general.
\end{abstract}

Key words: Rufje test, medical group, children mortality.

\section{Introduction}

A topicality of the problem of healthy lifestyle implementation in Ukraine is defined by extremely unsatisfactory main social and demographic index of the population's health state. In «Bloomberg» rating of the inhabitants health state of different countries, published in August 2012, Ukraine ranks 99 (between Iraq and Pakistan) among 145 other world countries. If to compare with other post Soviet countries: Georgia ranks 71, Russia - 97 (http:// images.businessweek.com/bloomberg/pdfs). The key social and demographic factors are at the critical level: natural population reduction (per 1000 people in 2011 it made up 3,7 people) high level of mortality (14,6 people per 1000 people) low birth rate level, disease incidence high level . In Ukraine the index of infant mortality is twice higher than in the developed countries (Posylannia presydenta Ukrainy, 2012). In the subjective self-evaluation of the Ukrainians health rate negative characteristics are mentioned.

According to the data provided by the State Service for Youth and Sport in Ukraine, total population in Ukraine in 2011 45617542, the total number of those who were engaged in physical culture and sport made up only 6228945 people, that was 13,65 \% (Ukrein sporting, 2012). At the end of 2011 the total of those who were going in for all kinds of health and fitness made only 4951946 (among them 2279347 were people of the age of 16-18 years old) (Statystychny shchorichnyk Ukrainy, 2012).

According to the data provided by World Health Organization total children mortality in the result of the accidents makes up 7,2 per 100 thousand of the boys and 22,8 per 100 thousand of the girls. The majority of the childrens' traumas younger than 13 year old happens at the school age during the games and sport activities (50 $\%) ; 30 \%$ at home and $20 \%$ - traffic accidents.

Despite the fact that regular physical activity and sport are beneficial and help to strengthen health, active physical exercises sometimes are connected with high risk of children and teens with high sensitivity to physical activity instant death (Orliaguet, Meyer, Blanot, Schmautz, Charron, Riou, Carli, 2001; Khodorivska, 2011). Protection of such children from extra risk very often needs certain restrictions of some kind of physical activity (Sirard, Pate, 2001). Although, potential efficiency of such measures depends on the defining of those people who are more or less risky (Bar-Or, Rouland, 2009).

Address for correspondence: Demianchuk Olena, Lesya Ukrainka East European National University, Prosp. Voli 13, Lutsk, 43025, Ukraine, e-mail: demolen@mail.ru phone: +38 (050) 672-58-38

Tables: 3, Figures: 0, References: 17, Full text PDF www.hpc.edu.pl Copyright (C) Pope John Paul II State School of Higher Education in Biała Podlaska, Sidorska 95/97, 21-500 Biała Podlaska Indexation: Index Copernicus, Database AGRO, ProQuest, Polish Ministry of Science and Higher Education. This is an open-access article distributed under the terms of the Creative Commons Attribution Non-commercial License (http://creativecommons.org/licenses/by-nc/3.0), which permits use, distribution, and reproduction in any medium, provided the original work is properly cited, the use is non-commercial and is otherwise in compliance with the license. 
There were 13 fatal cases at the physical training lessons for the last 6 years. Analyzing the reasons of these cases we found out that only one case was caused by trauma. 12 twelve other cases were caused by children's CVD.

Essential changes began in September 2009. The Ministry of Health and Education of Ukraine defined Rufje tests as sustainable to define children readiness for physical training lessons (http://moz.gov.ua/uaportal/ pre_20100706_0.html; moz.gov.ua/ua/main/press/?doklD =20700). Before the beginning of the academic year pediatricians carry out children medical examinations and on their results they divide them into the groups. There are no children who are released from the physical training lessons. Pupils with cumulative diseases or temporary problems go in for sport in a special group. The members of this group are defined by the pediatrician. The public resonance of this innovation cannot be compared to any other physical training pupils in the history.

The aim of the research is to analyze reliability and performance of the Rufje test and to establish efficiency of its application during the pupils division process into the groups for PT lessons.

Methods and materials of the research Rufje test is a small medical examination for a child that allows to establish the state of the child' heart. It is carried out by the next scheme. After 5-minute relaxation sitting on the chair the heart rate is taken during the 15 seconds (p1) and then a child crouches for thirty times for forty-five seconds. Immediately after crouching the heart rate is being taken for the first fifteen seconds (p2) and also during the last fifteen seconds (p3) of the first minute of the rest period. The results are estimated by the index defined by the formula:

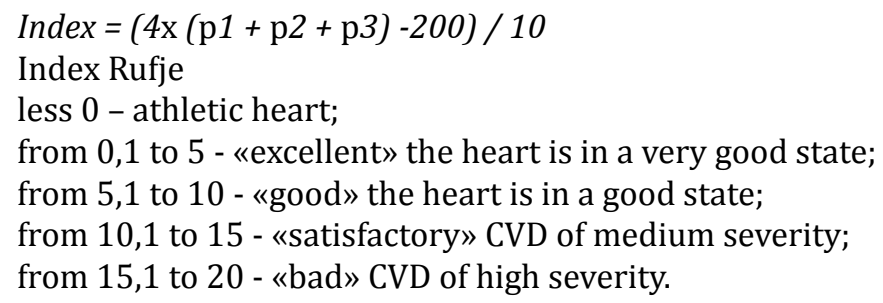

The children are divided into three groups only on the basis of the results of the Rufje test. The groups are: main, group with reduced load and a special group (a group with special exercise load (table 1).

Table 1. Characteristics of the groups for PT lessons

\begin{tabular}{|c|c|}
\hline Name of the group & Criteria for the enrollment of the pupils into the group \\
\hline Main group & $\begin{array}{c}\text { Absolutely healthy children which after the medical check-up and Rufje test appear to } \\
\text { have no problems. They go in for physical activity and can participate in cross-country } \\
\text { races and competitions. }\end{array}$ \\
\hline A group with reduced load & $\begin{array}{c}\text { The children with slight deviations from the norm (1-2 degree diffuse goiter, fault in } \\
\text { posture, 1-degree scoliosis) and Rufje index - lower than the norm. These children do } \\
\text { sport according to the basic program but they are released from such physical loads as } \\
\text { cross-country races and other sport events. }\end{array}$ \\
\hline Special group & $\begin{array}{c}\text { Here are the children whose state of health needs a special individual approach when } \\
\text { defining a physical load for them. A PT teacher defines for them a special program. These } \\
\text { children are included to the pertaining to the prophylaxy group of observation where } \\
\text { their chronic pathology is observed. }\end{array}$ \\
\hline
\end{tabular}

Sometimes the state of the child allows his/her enrollment to the main group but according to the Rufje test the heart may not bear the load and that is a child is enrolled to the group with reduced load. Later the Rufje test is taken again - in a month or two.

Results of the research: we are having at our disposal the statistics provided by Ministry of Education the out-of-school and sport establishments on the $1^{\text {st }}$ of January 2011 . We have noticed the regularity - in those regions where children died during the PT lessons, the sport clubs make the least quantity (table 2).

Table 2. Quantity of children in sport clubs

\begin{tabular}{|c|c|c|c|c|c|}
\hline Region & Q-ty of sport clubs & Children involved & Region & Q-ty of sport clubs & Children involved \\
\hline Crimea & 72 & $33,4 \%$ & Odesska & 108 & $36,1 \%$ \\
\hline Vinnytska & 61 & $24,0 \%$ & Poltavska & 85 & $30,7 \%$ \\
\hline Volynska & 63 & $34,0 \%$ & Rivnenska & 58 & $30,6 \%$ \\
\hline Dnipropetrovska & 179 & $39,9 \%$ & Sumska & 76 & $58,1 \%$ \\
\hline Donetska & 147 & $34,5 \%$ & Ternopilska & 66 & $33,5 \%$ \\
\hline
\end{tabular}




\begin{tabular}{|c|c|c|c|c|c|}
\hline Zhytomyrska & 65 & $38,1 \%$ & Kharkivska & 107 & $47,2 \%$ \\
\hline Zakarpatska & 48 & $35,3 \%$ & Khersonska & 77 & $36,7 \%$ \\
\hline Zaporiz'ka & 81 & $36,3 \%$ & Khmelnytska & 73 & $37,1 \%$ \\
\hline Ivano-Frankivska & 72 & $37,4 \%$ & Cherkasska & 70 & $34,6 \%$ \\
\hline Kyivska & 89 & $45,2 \%$ & Chernivetska & 44 & $31,8 \%$ \\
\hline Kirovohradska & 51 & $53,4 \%$ & Chernihivska & 67 & $40,9 \%$ \\
\hline Luhanska & 108 & $41,7 \%$ & Kyiv & 70 & $42,8 \%$ \\
\hline L'vivska & 123 & $31,0 \%$ & Sevastopol & 13 & $44,3 \%$ \\
\hline Mykolaivska & 61 & $37,6 \%$ & Total & 2134 & $37,5 \%$ \\
\hline
\end{tabular}

(In bold are the regions where for the last year the children died during the PT lesson).

According to the data of anonymous questionnaire conducted among the pupils and teens' parents, we received the following results:

» for $31 \%$ of the pupils their physical activity is limited by their walking from school to home;

» more than $1 / 3$ of parents don't know anything what their children are doing after school;

» almost $45 \%$ of the pupils spend less than one hour a day in the open air;

» $1 / 4$ of the parents «solve» the issue of visiting (better to say not visiting) the PT lessons by their children with the help of the certificates from the doctors or immediately with the PT teachers.

The statistics says: among the surveyed pupils of 15-16 years old 25\% used alcohol drinks at the age of 13 , $40 \%$ of the children at the age of 11-12 tried alcohol, and $20 \%$ of the sixth form pupils were once drunken. $20-$ $25 \%$ of the youngsters began to smoke at the age of 11 or even earlier. Among the girls $25-40 \%$ first smoked at the age of $14-15.8-26 \%$ of the teens were abusing drugs at the age of 13-16. The majority of the surveyed do sports less than a half of an hour or an hour per week. 75\% spend watching TV from one to four hours. 65-90\% sit at the computer from half an hour to three hours a day. About $60 \%$ of the parents and $40 \%$ of the mothers know little or nothing at all about how their children free time. We have cases, especially in big cities, when $38 \%$ of pupils are released from the PT lessons. There may be only reason defined: lack of fashion, wish and popularity of the PT lessons and general interest to go in for sport.

Every tenth school doesn't have gym. And $40 \%$ of the existing gyms do not meet modern requirements. Thus, about half of the pupils do not have an opportunity to have comprehensive PT lessons and to go in for sport.

State standards provided maximum physical load on a child. But a child does not need them. The PT lessons should be health-improving (Reznik 2011). Neither seconds nor kilometers can define physical state of a child, but it is a physical development that must do this, namely: weight and height. Development of the standards of the physical load at the PT lessons should be based first of all on the health indicators of the children and abilities of the child's body to fulfill them. According to the data of the research, only $30 \%$ of the children can fulfill these standards without any risk to their life. The processes of renewal of the fitness shape after fulfilling the standards are flowing in the norm only with $18-24 \%$ of the children. These are the data concerning the children which are absolutely healthy and have no diagnosis.

Discussion of the results: it is clear even for an outsider that such a situation is not normal but unfortunately, neither doctors nor PT teachers are not ready to express their opinions about the advisability of the Rufje test.

It is known that now this test can be taken in clinical conditions both with teens and adults which were checked-up and were recognized healthy. This test gives an opportunity to define functional characteristics of the cardiovascular system, in the other words, the level of the fitness of the heart in the process of selection of the students of the military schools or at the draft to the Army. But the question is whether this system is suitable for the pupils, especially junior ones?

In accordance with the recommendations of the WHO, when conducting the functional tests the load must not exceed $75 \%$ of the maximal possible load. It has been proved in practice that pulse frequency of 170 beats per minute testifies to the maximal load on the heart. When taking Rufje test a child has to crouch thirty times within 45 seconds. Doing this many adults and children have the heart rate up to 170 beats per minute. Some junior pupils can hardly bear such a testing. Rhythm disturbance and arterial tension hypotony may happen. Taking into account functional, and anatomical immaturity of the cardiovascular, nervous and vegetative systems as well as psychological factor during the Rufje testing, many specialists are apt to think that this test is not advisable and may be even risky for juniors. Sometimes children get pale, faint and this means that such an experiment for some of them may have rather negative results. 
We suppose that evaluating Rufje test is necessary to take into account the methods of testing and age of the pupils. So, the pulse rate up to 12 years, instability of the neural processes with children of this age are often stipulate high Rufje index and this is considered to be the reason, though groundless, for the enrollment of a child to the group with lower level of load (Romaskevych 2011).

Age standards for the evaluation of the Rufje test are proposed in the scientific research conducted by A.A. Huseva, S.D. Poliakova and I.H. Korneieva. The research was conducted at the Federal Centre of Exercise Therapy and Sports Medicine of the Ministry of Health of Ukraine. The standards received are contained in the table 3.

Table 3. Evaluation of the Rufje test with children with consideration of age factor

\begin{tabular}{|c|c|c|c|c|c|}
\hline \multirow{2}{*}{ Evaluation of the result } & \multicolumn{5}{|c|}{ Rated Rufje test according to age } \\
\cline { 2 - 6 } & $\mathbf{1 5}$ years and older & $\mathbf{1 3 - 1 4}$ years & $\mathbf{1 1 - 1 2}$ years & $\mathbf{9 - 1 0}$ years & $\mathbf{7 - 8}$ years \\
\hline Not satisfactory & 15 & 16,5 & 18 & 19,5 & 21 \\
\hline Poor & $11-15$ & $12,5-16,5$ & $14-18$ & $15,5-19,5$ & $17-21$ \\
\hline Satisfactory & $6-10$ & $7,5-11,5$ & $9-13$ & $10,5-14,5$ & $12-16$ \\
\hline Good & $0,5-5$ & $2-6,5$ & $3,5-8$ & $5-9,5$ & $6.5-11$ \\
\hline Excellent & 0 & 1,5 & 3 & 4,5 & 6 \\
\hline
\end{tabular}

The parents who worry that their children may have health problems, need to know that Rufje index 1-6 occurs with people with trained heart who seriously go in for sport. If the index is 7-15 - they are practically healthy children but they move little in their everyday activity. They are the children for whom physical training lessons could be highly effective. The children having index, need serious medical examination, and after excluding serious illnesses they are also recommended physical exercises but under the doctor's control. Healthy but poorly fit pupils the Rufje index improves very quickly if they run, move a lot, if they like cycling and games in the open air. Unfortunately, today thanks to bureaucrats' ability, more than $80 \%$ of children are factually recognized as having heart problems and are almost released from the PT lessons.

And what is worse, there are not many absolutely healthy pupils, and near $30 \%$ of the future first-graders have some chronic illnesses. The doctors have also underlined that according to the results of the Rufje test applied for the evaluation of the heart performance at the physical load, $42 \%$ of the pupils should be enrolled to the special groups.

\section{Conclusions}

With an account of all abovementioned we can draw such conclusions:

1. The system of physical control and regular medical check-ups of the pupils need radical improvement. These tragic cases are also the reasons to state that parents know little about the state of health of their children. And even when they know about the problems, they do not inform the school.

2. It is necessary to provide a differentiated approach to the pupils at the PT lessons and to make a studying process individual. In the course of preparation of the specialists on physical culture and sport it is necessary to increase a number of classes devoted to teaching biology, physiology and medicine. Retraining of the specialists is also a must.

3. It is also necessary to increase a quantity of the sport competitions held at different levels, and together with sport organization to conduct master-classes involving in this activity leading specialists of our country, and to conduct lessons on those sports which are interesting to pupils.

\section{References:}

1. Бар-Ор О., Роуланд Т. (2009) Здоровье детей и двигательная активность: от физиологических основ до практического приминения; пер. с англ. И. Андреев., К: Олимп. л-ра, 528, ил. - Библиогр.: стр. $457-527$.

2. Громадські організації в Україні у 2011 році (2012) Стат. Бюлетень, Державна служба статистики України, К:, 8.

3. Про внутрішнє та зовнішнє становище України в 2012 році (2012) Щорічне Послання Президента України до Верховної Ради України, К.: НІСД, 98.

4. Резнік О. (2011) Громадянські практики в перехідному суспільстві: чинники, суб’єкти, способи реалізації. О. Резнік; К.: Інститут соціології НАН України, 264. 
5. Результати національних моніторингових опитувань 1992 - 2011 років (2011) Українське суспільство. Двадцять років незалежності. Соціологічний моніторинг: У 2-х т. - Т. 2, К.: Інститут соціології НАН України, 72.

6. Ромаскевич Ю.О. (2011) Корекція стану фізичного здоров’я учнівської та студентської молоді засобами лікувальної фізичної культури. Ю. О. Ромаскевич, (22-23 вересня 2011 р.) : матеріали IX Всеукр. наук.практ. конф. «Актуальні проблеми юнацького спорту», Херсон: ПАТ Херсон. міськ. друк., стр. 165-166.

7. Статистичний щорічник України за 2011 рік (2012) Державна служба статистики України, К.: ТОВ «Август Трейд», 490.

8. Сущенко Л. П. (1999) Соціальні технології культивування здорового способу життя. Л. П. Сущенко; Запоріжжя: Запорізький державний університет, 7.

9. Україна спортивна 2010 - 2011 роки (2012) Інформаційний довідник; Державна служба молоді та спорту України, К:, 25.

10. Ходорівська Н. (2011) Адаптивні ресурси людини в контексті українських реалій. Українське суспільство. Двадцять років незалежності. Соціологічний моніторинг: У 2-х т. - Т. 1. - К: Інститут соціології НАН України, 423.

11. Orliaguet G., Meyer P., Blanot S., Schmautz E., Charron B., Riou B., Carli P. (2001) Validity of applying TRISS analysis to paediatric blunt trauma patients managed in a French paediatric level I trauma centre. Intensive Care Med.; Apr. - 27(4): 743-50.

12. Sirard J. R., Pate R. R. (2001) Physical activity assessment in children and adolescents. Sports Med.; 31(6): 439-454.

\section{Web pages:}

13. The World's Healthiest Countries http://images.businessweek.com/bloomberg/pdfs/WORLDS_HEALTHIEST_ COUNTRIES_V2.pdf

14. htpp://ogo.ua/articles/view/2012-01-28/31915.html

15. htpp://www.unian/news/483590-chomu-diti-pomiraut-na-fizkulturi.html

16. http://moz.gov.ua/uaportal/pre_20100706_0.html

17. moz.gov.ua/ua/main/press/?doklD $=20700$

Submitted: 16.06 .2014

Accepted: 08.09.2014 